\title{
Two-end-member mixing in the fluids emitted from a sediment hosted geothermal system, mud volcano Lei-Gong-Huo, Eastern Taiwan: Evidence from $\mathrm{Sr}$ isotopes
}

\author{
H. C. $\mathrm{CHAO}^{1 *}$, C. F. YOU ${ }^{2}$, C. C. HUANG ${ }^{1}$
}

${ }^{1}$ Department of Earth and Environmental Sciences, National Chung Cheng University, Chiayi, Taiwan (* correspondence: ekman60@gmail.com)

${ }^{2}$ Department of Earth Sciences. National Cheng Kung University, Tainan, Taiwan

Mud volcanoes are one of the most important conduits for deep seated materials to migrate upward in sedimentary basins, convergent margin, and subduction zones. Understanding their temporal and spatial characteristics and variations provides us the important information on fluid sources and chemical compositions in depth. Mud volcano Lei-Gong-Huo (MV LGH) is a unique mud volcano which is located on the mélange formation lying on the andesitic volcanic arc. Fluids emitted from 47 setalite mud volcanoes in MV LGH were sampled and measured their major, trace elements with ${ }^{87} \mathrm{Sr} /{ }^{86} \mathrm{Sr}$ ratios. Major elements of the fluids are $\mathrm{Cl}, \mathrm{Na}$ and $\mathrm{Ca}$, which are distributed between 291 and $376 \mathrm{mM}, 131$ and $289 \mathrm{mM}$, and 48.9 and $313 \mathrm{mM}$, respectively. High content of $\mathrm{B}, \mathrm{Ba}, \mathrm{Mn}$, and $\mathrm{Sr}$ with relative low concentration of $\mathrm{S}$ and alkalinity are also detected. Comparing with seawater, LGH fluids have lower $\mathrm{Na} / \mathrm{Cl}$, $\mathrm{K} / \mathrm{Cl}$, and $\mathrm{Mg} / \mathrm{Cl}$ but higher $\mathrm{Ca} / \mathrm{Cl}$ ratios, indicating waterrock interaction of igneous rock and paleo-seawater at source region. This interpretation has further supported by $\mathrm{Sr}$ isotopes, which show low value of ${ }^{87} \mathrm{Sr} /{ }^{86} \mathrm{Sr}$ ratio down to 0.70710. The result of spatial distribution showing strong negative correlation between $\mathrm{Na}, \mathrm{Ca}$ concentration and $\mathrm{Ca}$, ${ }^{87} \mathrm{Sr} /{ }^{86} \mathrm{Sr}$ ratios indicates two end-member mixing is the major chemical characteristic. The fluid interacts with igneous rock carrying high $\mathrm{Ca}$, low $\mathrm{Na}$ and low ${ }^{87} \mathrm{Sr} /{ }^{86} \mathrm{Sr}$ ratio while those interact with sedimentary rock carrying low $\mathrm{Ca}$, high $\mathrm{Na}$ and high ${ }^{87} \mathrm{Sr} /{ }^{86} \mathrm{Sr}$ ratio. The source from igneous region dominates eastern part of the mud volcanoes in LGH while sedimentary source dominates western part. Most mud volcanoes show mixing behavior between two sources. In summary, fluids emitted from mud volcanoes in LGH are originated from two sources, which are water-rock interaction of igneous rock with paleo-seawater from the east and sedimentary rock from the west at depth, resulting from complex geologic background of mélange formation. 